\title{
Root Distribution of Four Tree Species Planted in Living Hedges according to Two Types of Soil and Three Agroforestry Technologies in the Sudano-Sahelian Zone of Cameroon
}

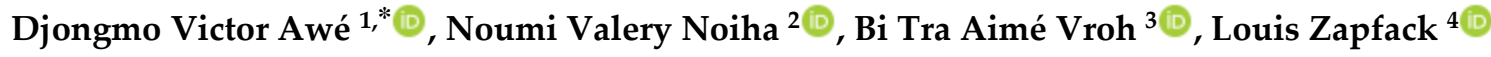 \\ ${ }^{1}$ Faculty of Sciences, University of Ngaoundere, Cameroon \\ ${ }^{2}$ Higher Teacher Training College of Bertoua, University of Ngaoundere, Cameroon \\ ${ }^{3}$ UFR BioSciences, University Félix Houphouët-Boigny, Abidjan, Côte d'Ivoire \\ ${ }^{4}$ Faculty of Sciences, University of Yaounde I, Cameroon \\ *Correspondence: awevictor20@yahoo.fr
}

How to cite this paper: Awé, D. V., Noiha, N. V., Vroh, B. T. A., \& Zapfack, L. (2021). Root Distribution of Four Tree Species Planted in Living Hedges according to Two Types of Soil and Three Agroforestry Technologies in the Sudano-Sahelian Zone of Cameroon. Open Journal of Agricultural Research, 1(2), 74-83. Retrieved from https://www.scipublications.com/journal/in-

dex.php/ojar/article/view/138

Received: August 20, 2021

Accepted: September 24, 2021

Published: September 25, 2021

Copyright: () 2021 by the authors. Submitted for possible open access publication under the terms and conditions of the Creative Commons Attribution (CC BY) license (http://creativecommons.org/licenses /by/4.0/).

\begin{abstract}
In the agroforestry systems of sub-Saharan Africa, the vertical and horizontal distribution of tree root biomass according to the soil profile is still poorly documented. The objective of this study is to verify the root distribution of four species of trees established in living hedges, namely, Commiphora kerstingii, Erythrina sigmoidea, Ficus thonningii and Jatropha curcas according to two types of soil (light soil and heavy soil) and three agroforestry technologies (fallows, wooded parks and plantations). The hedges were mostly monospecific in order to facilitate the identification of the roots. The experimental set-up is an entirely random factorial design with two factors. The evaluation of the distribution of tree roots was carried out using the profile method. To determine the different textural classes, a particle size analysis was undertaken in the laboratory. The results obtained show that the number of roots decreases rapidly after $30 \mathrm{~cm}$ of depth. The highest root densities are observed in the first $30 \mathrm{~cm}$. Soil type has a slight effect $(p<0.05)$ on rooting density in the last $30 \mathrm{~cm}$ of depth for all root classes, higher densities were obtained in light soil compared to heavy soil. Commiphora kerstingii stands out significantly by obtaining a higher number of roots than the other species for all classes. Among the technologies, the plantations showed the lowest root density at $0-5 \mathrm{~cm}$ and the highest at $55-60 \mathrm{~cm}$. The root density was higher in the fallows. The results show that the root system is mainly concentrated near the stump.
\end{abstract}

Keywords: Agroforestry technologies, Living hedges, Roots

\section{Introduction}

In botany, the root is the underground organ of a plant serving to fix it to the soil and to draw the water and nutrients necessary for its development [1,2]. It is the prolongation of the stem downwards; it differs from it in several characteristics: its internal structure, its positive geotropism, the presence of a terminal cap and absorbent hairs, the absence of leaves and buds $[2,3]$. It is this last characteristic which fundamentally distinguishes it from the stem. The roots are often the seat of symbiosis with bacteria and fungi in the soil, in particular for nitrogen metabolism [2-4]. The roots can show adaptations in order to facilitate the development of the plant in a particular environment [2-5]. In some roots are also used to store nutrients [2]. Some plant roots are edible or for medicinal use, others are highly toxic. The roots are the target organs of root herbicides, which are used to control weeds [6]. 
The distribution of vascular plant roots in the soil depends on the shape of the plants, the spatial and temporal distribution of water and nutrients, and the physical properties of the soil itself [6,7]. The deepest roots are generally found in deserts and in temperate coniferous forests; the shallower ones are found in tundra, boreal forests and temperate grasslands. In fissured bedrock, the central roots can continue their vertical extension [6,7]. The strategies for occupying the underground environment by root systems can be summed up in two main situations: an extensive exploration of the soil which is carried out by the periphery of the system or an exploration and intensive exploitation of the soil in which the entire root system is involved[7-9]. In general, most of the active roots of trees which ensure the absorption of mineral ions and water are shallow roots (between 50 and $80 \%$ depending on the species and the environment, located in the first 20 to 30 centimeters of the soil) forming the hairy deciduous root in the short term, the perennial woody roots (superficial and deep roots with a diameter of more than $1 \mathrm{~cm}$ ) which constitute the root framework essentially ensuring the anchoring and the deciduous woody roots specializing in colonization and 1 use of the soil[7,8,10,11]. Hence the presence of the study aims to verify the root distribution of four species of trees established in living hedges, namely, Commiphora kerstingii, Erythrina sigmoidea, Ficus thonningii and Jatropha curcas according to two types of soil (a light soil and a soil heavy) and three agroforestry technologies (fallows, wooded parks and plantations) in the Sudano-Sahelian zone of Cameroon.

\section{Materials and Methods}

\subsection{Study area}

The study occurred in Central Africa, more precisely in Cameroon, in the North region of Cameroon. This region is located between $7.2^{\circ} \mathrm{N}$ to $9.99^{\circ} \mathrm{N}$ latitude and $12.6^{\circ} \mathrm{E}$ to $15.3^{\circ} \mathrm{E}$ longitude (Figure 1)[2]. The relief is a vast pedi-plain between the Mandara Mountains $(1442 \mathrm{~m})$ to the north and the Adamawa Plateau to the south. [2].The climate is of the Sudano-Sahelian type with two seasons: a dry season lasting six months (NovemberMay) and a rainy season lasting six months (June-October) [2]. The average monthly temperature varies from $26^{\circ} \mathrm{C}$ in August to $40^{\circ} \mathrm{C}$ in March (extreme temperatures: $17^{\circ} \mathrm{C}$ to $40^{\circ} \mathrm{C}$ ) [2]. The soil is of the ferruginous type characterized by acidity ( $\mathrm{pH}=5.5$ to 6 ) and low cation exchange capacity [2]. The vegetation is a shrubby Sudano-sahelian savannah with a clear and degraded Savannah appearance around the villages [2]. Agriculture is the main activity of the people of the region. The population practices subsistence agriculture (corn, peanuts and millet)[2].The administrative region of Northern Cameroon comprises four subdivisions, namely, Bénoué, Faro, Mayo Louti, and Mayo Rey (Figure 1). 


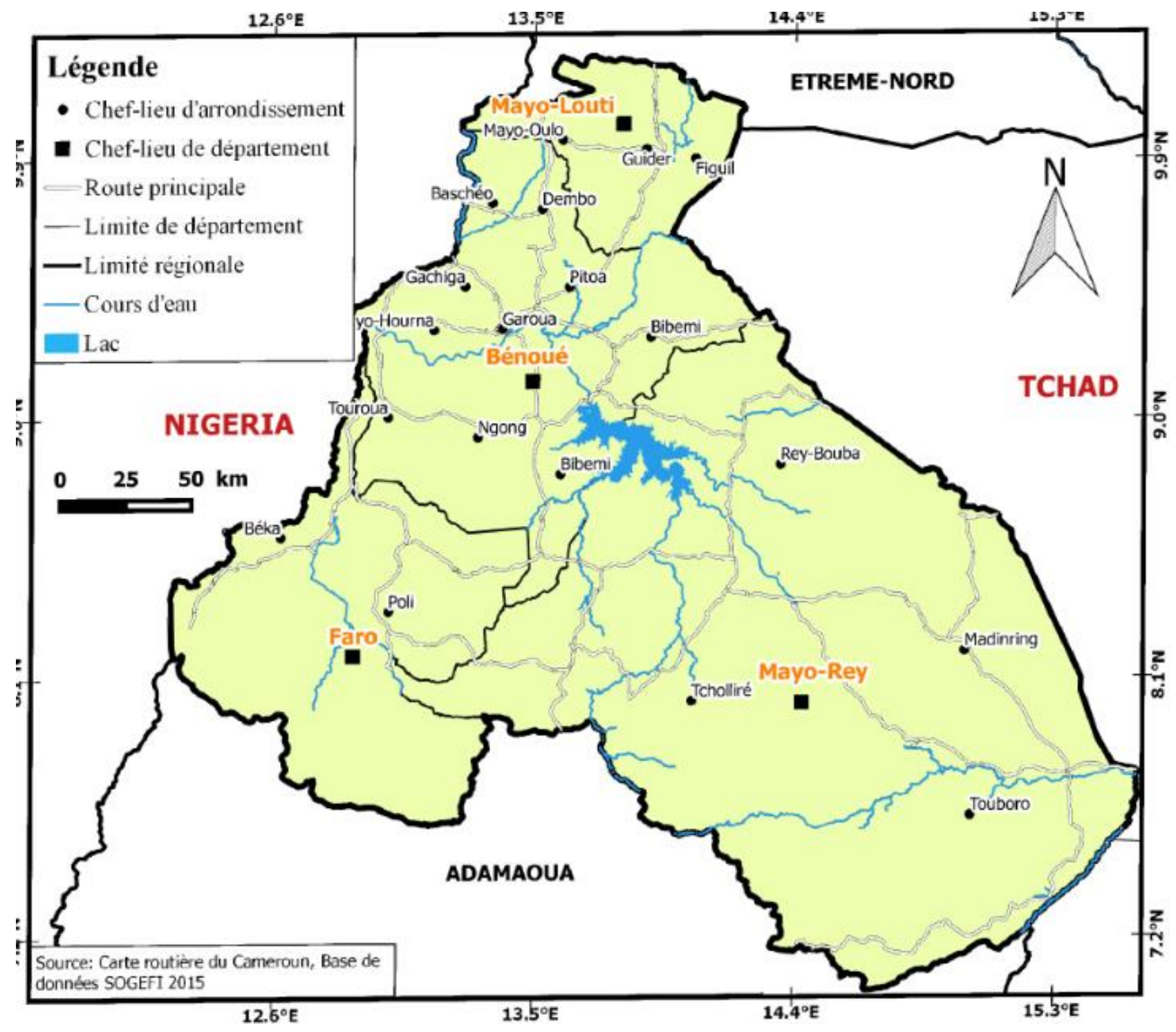

Figure 1. The geographic location of the study area in the North Region of Cameroon

\subsection{Choice of study sites and experimental design}

The hedges were mostly monospecific in order to facilitate the identification of the roots. The choice of trees studied inside the hedges was made according to the general appearance of the tree (absence of signs of disease) and its representativeness of the entire hedge (similar height and diameter).

The experimental design consisted of an entirely random factorial type design with two factors under study; the two types of soil and the four species that make up living hedges. This set-up consisted of three replicates, for a total of 24 experimental units. For each hedge, three transects were considered.

\subsection{Data collection}

The tree root distribution was assessed using the profile method [7]. This method consists of studying the roots on the smooth walls of open trenches where the roots are to be observed. The trenches were straight, about $80 \mathrm{~cm}$ wide by $60 \mathrm{~cm}$ deep. Three transects spaced at least 5 meters apart were drawn perpendicular to the line of trees on each site.

The trenches of each transect were dug in the adjacent field on the side of the row of trees which presented no constraint, sometimes downwind, sometimes upwind. The first 
trenches were dug parallel to the hedges at a distance of one meter from the tree. This distance generally corresponds to the place where the main roots (anchorage) are subdivided into secondary or oblique taproots, medium roots and fine roots [8]. Subsequently, we dug trenches along each transect at distances of $30 \mathrm{~cm}$ and $50 \mathrm{~cm}$. In this regard, if no root was observed at $50 \mathrm{~cm}$, then there was no count at $60 \mathrm{~cm}$.

The sites were visited during the months of July, August, September, October, November and December 2020 in order to carry out the necessary measurements. The trenches were dug using a mechanical shovel. The soils were slightly smooth with a shovel or trowel to facilitate observation of the roots. The roots were counted immediately after their exposure. In order to facilitate this procedure, we have placed a frame of $1 \mathrm{~m} \times 1 \mathrm{~m}$ on the wall. The interior of this frame was subdivided into squares of $10 \mathrm{~cm} \times 10 \mathrm{~cm}$. This made it possible to determine the root density (number of roots $/ \mathrm{dm}^{2}$ ) according to each depth stratum: $0-5 \mathrm{~cm}, 5-10 \mathrm{~cm}, 10-15 \mathrm{~cm}, 15-20 \mathrm{~cm}, 20-25 \mathrm{~cm}, 25-30 \mathrm{~cm}, 30-35 \mathrm{~cm}, 35-40$ $\mathrm{cm}, 40-45 \mathrm{~cm}, 45-50 \mathrm{~cm}, 50-55 \mathrm{~cm}$ and $55-60 \mathrm{~cm}$. The vertical distribution was obtained by observing the rooting depth.

The diameters have been grouped into four classes; class 1: roots $<1.0 \mathrm{~mm}$ (fine roots); class 2: roots from 1.1-5.0 $\mathrm{mm}$ (small roots); class 3: roots 5.1-10 $\mathrm{mm}$ (medium roots) and class 4: roots $>10 \mathrm{~mm}$ (coarse roots). Root densities are also presented for each of the diameter classes; class 1 (fine roots), class 2 (small roots), class 3 (medium roots) and class 4 (coarse roots).

Particle size analysis was determined by the Robinson's pipette method on air-dried soil samples sieved at $2 \mathrm{~mm}$. The organic matter has previously been destroyed by attack with hydrogen peroxide. The sol was then dispersed by rotary shaking in flasks after addition of sodium hexa-metaphosphate (NaPO3)6. The different particle size fractions were determined by pipetting for the clayey and silty fractions and by sieving for the sand. The textural classes were found using the FAO Textural Triangle, once the proportions of the different textural fractions were calculated.

\subsection{Data analyses}

The data were encoded in EXCEL software and then analyzed using STATGRAPHICS plus 5.0 and R software. Analysis of variance (ANOVA) was used to test the existence or not of a significant difference in the difference parameters. Duncan test at 0.05 was used to compare parameter means.

\section{Results}

\subsection{Root density by diameter class according to the four species}

The root density of four species varied depending on the diameter class of the roots. The highest root density was observed in class 2 . Commiphora kerstingii stands out significantly by obtaining a higher number of roots than the other species for all (Figure 2). 


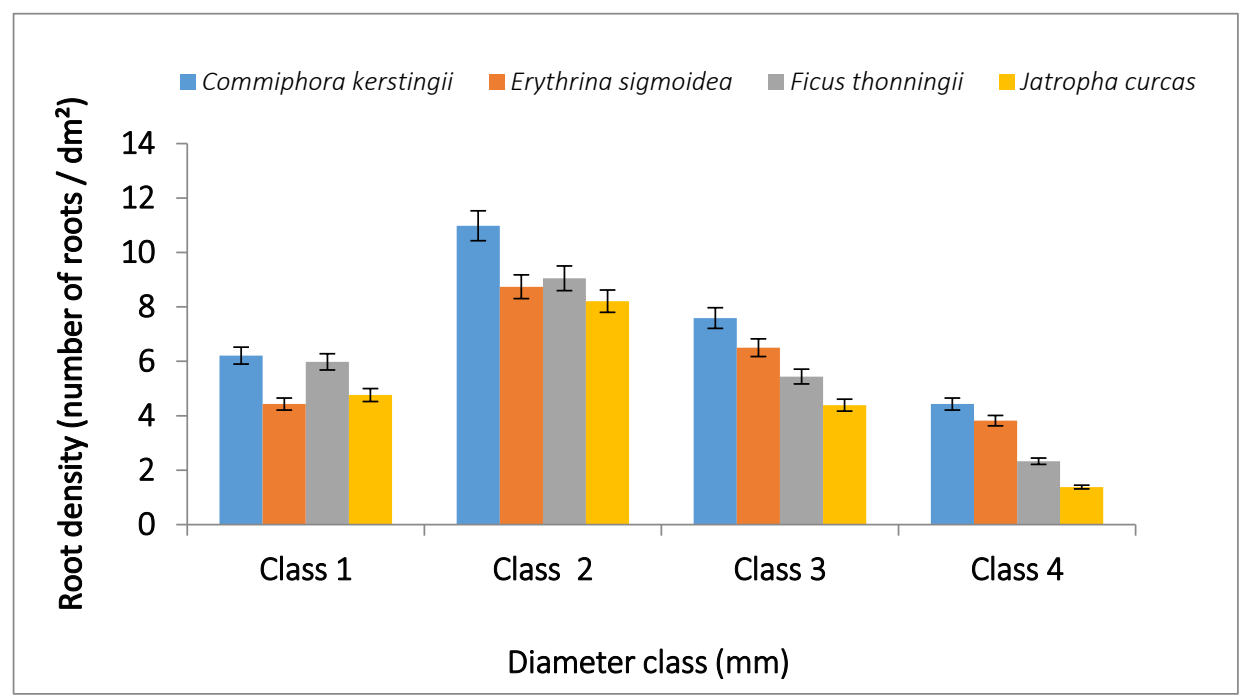

Figure 2. Root density by diameter class according to the four species

\subsection{Root density of the four species as a function of soil texture and depth}

The root density of four species varied depending on the soil texture. The highest root density was observed in clay soils, followed by sandy loam, sandy and silty soils (Figure 3). In all textural classes, Commiphora kerstingii exhibits the highest root densities compared to the other three species. The analysis of variance shows a significant difference between the root density of the species and the textural class of the soil $(\mathrm{P}<0.05)$ (Figure 3). The highest root densities were observed in the surface layers of the soil, ie in the first $30 \mathrm{~cm}$ (Figure 4). The analysis of variance shows a significant difference between the root density of the species and the depth of the soil $(\mathrm{P}<0.05)$ (Figure 4 ).

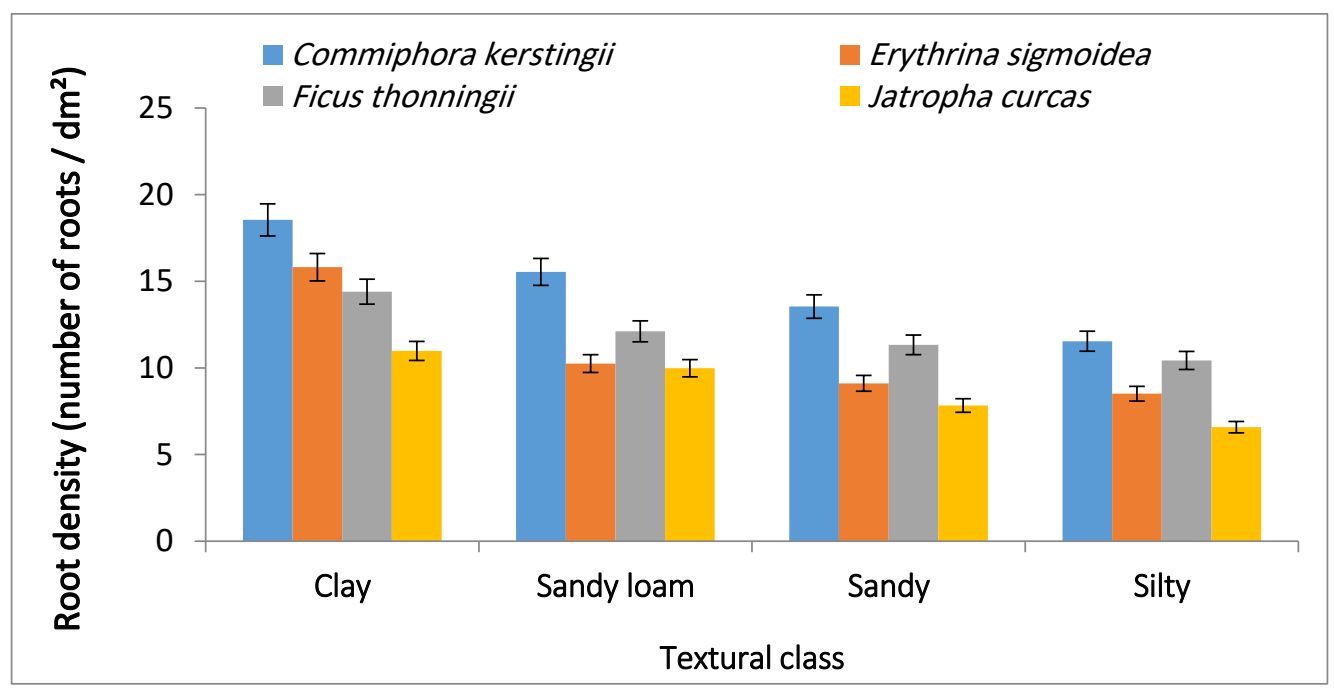

Figure 3. Root density of the four species according to soil textures 


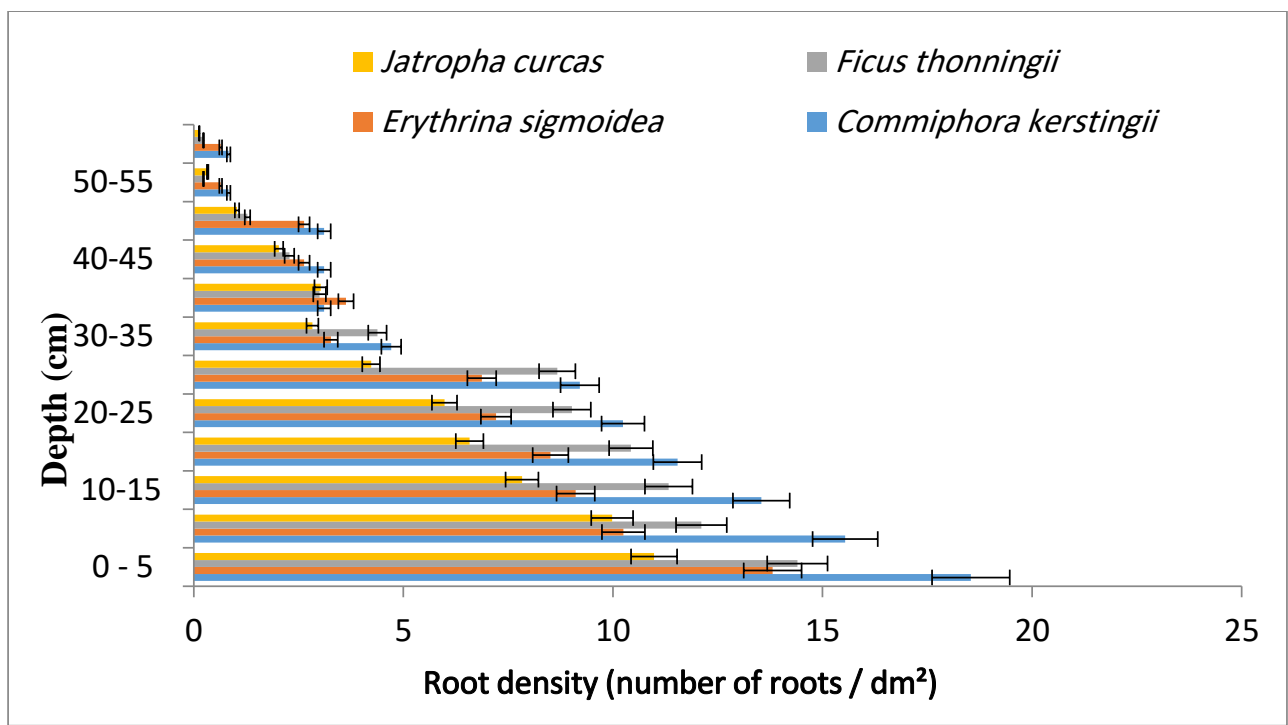

Figure 4 . Root density by depth class according to the four species

\subsection{Root density according to the four species}

The root density according to the four species was different according to the $60 \mathrm{~cm}$ depth of the soil. Analysis of variance shows a very significant difference between the four species and their root densities $(\mathrm{P}<0.05)$. The highest root densities were observed in Commiphora kerstingii (113.7 roots / $\left.\mathrm{dm}^{2}\right)$, followed by Ficus thonningii $\left(93.42\right.$ roots $\left./ \mathrm{dm}^{2}\right)$, Erythrina sigmoidea (74.66 roots / $\mathrm{dm}^{2}$ ) and finally Jatropha curcas (55.06 roots / $\mathrm{dm}^{2}$ ) (Figure 5).

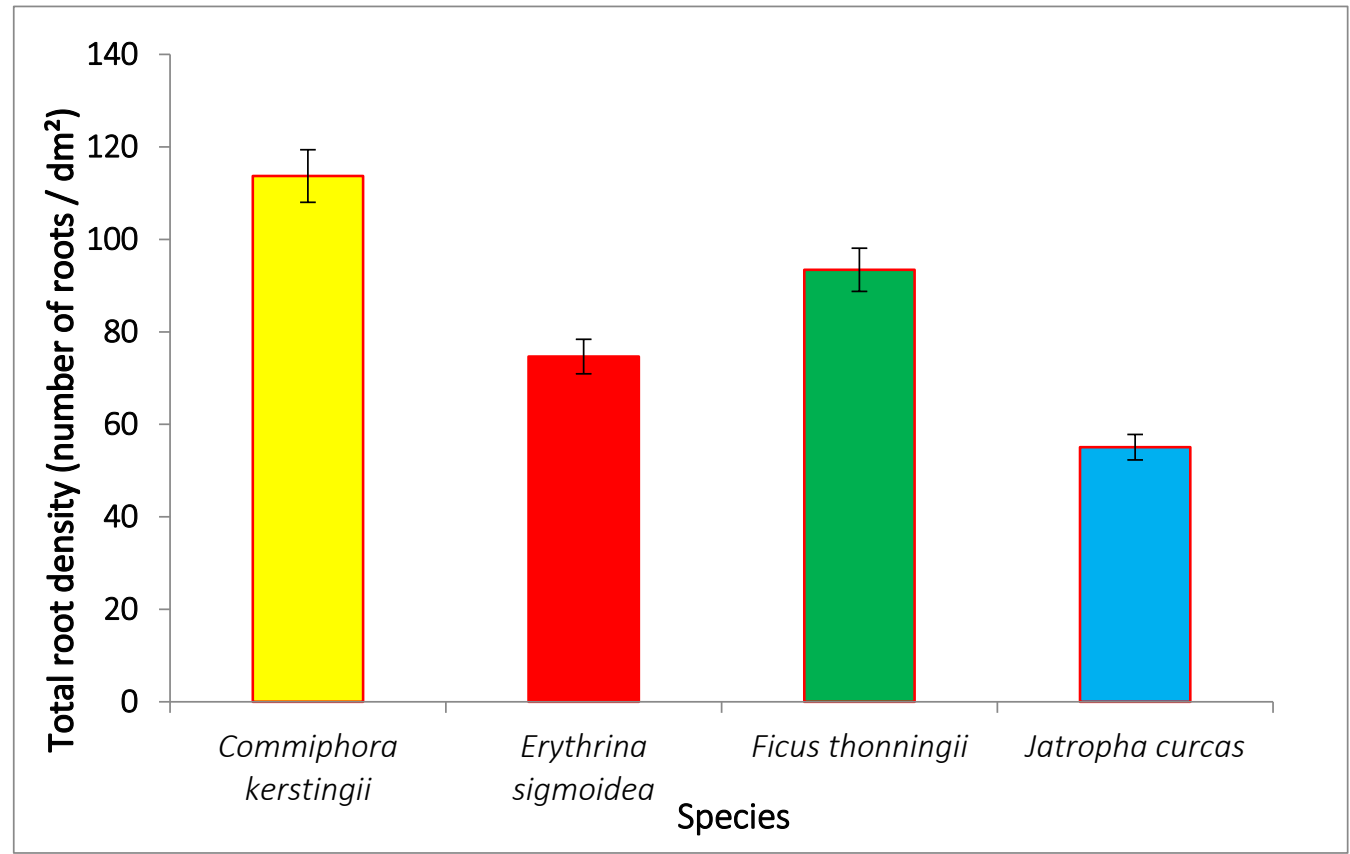

Figure 5. Root density according to the four species over the $60 \mathrm{~cm}$ depth of the soil

\subsection{Root density by depth class according to soil types and according to the combination of the two soil types}

There is an exponential decrease in root density by depth class depending on the type of soil. In the case of light soils, after a constant decrease, the root density stabilizes in the 
45-60 cm stratum. For heavy soils, the decrease in root density is constant. Thus, the highest root densities are reached in the surface layer. The highest densities are observed in light soil compared to heavy soil (Figure 6). The root densities are higher in the 0-5 $\mathrm{cm}$ depth (56.35 roots $/ \mathrm{dm}^{2}$ ) and lowest in the depths 55-60 cm (6 roots / $\mathrm{dm}^{2}$ ) (Figure 7). Depending on the combination of the two soil types, the highest root densities which decrease with increasing depth (Figure 7).

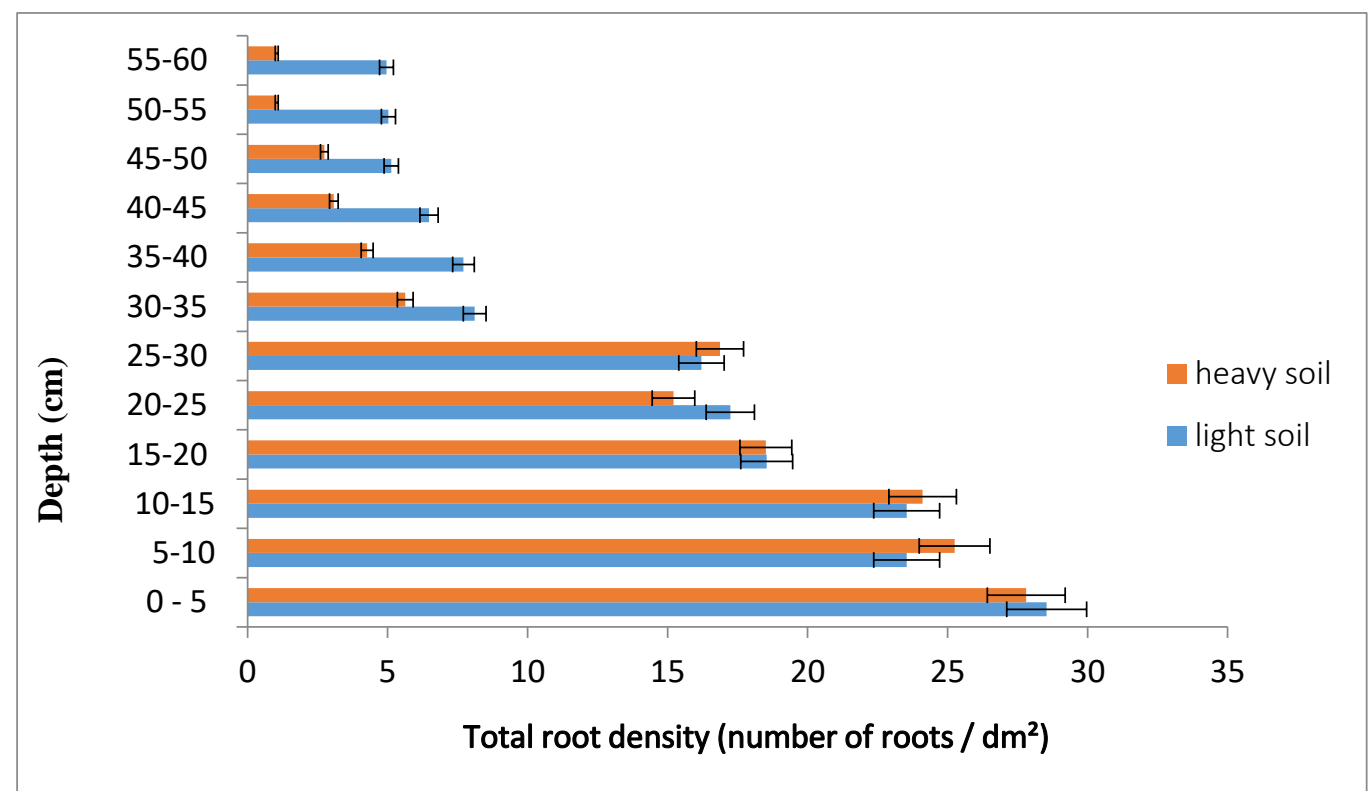

Figure 6. Root density by depth class according to soil types

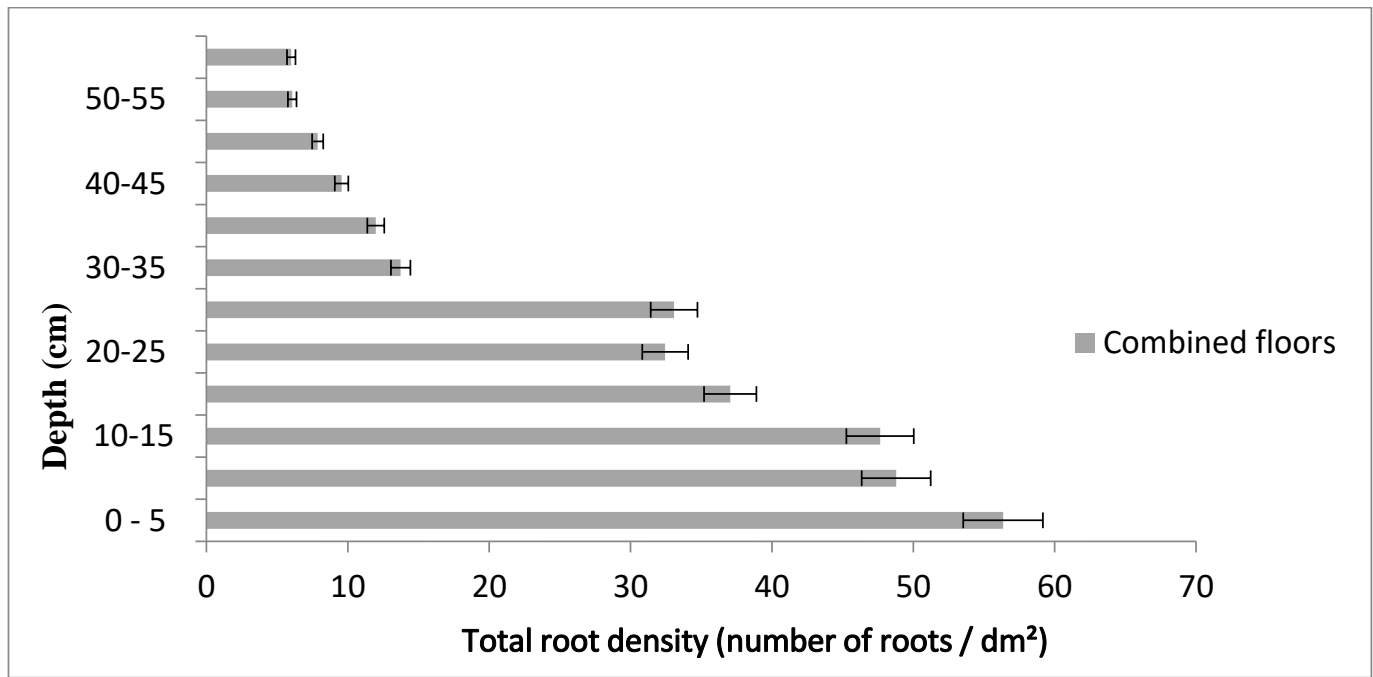

Figure 7. Root density by depth class according to the combination of the two soil types

\subsection{Root density of four species depending on agroforestry technology and soil depth}

The root density of four species also varied depending on the depth in the three agroforestry technologies (Figure 8). In general, for all depths, the highest root density was observed in fallows (Figure 8). In all technologies, the lowest root density was significantly observed at 0-5 cm and 55-60 cm. Among the technologies, the plantations showed the lowest root density at $0-5 \mathrm{~cm}$ and the highest at $55-60 \mathrm{~cm}$ (Figure 8). On the other hand, for all technologies, the highest root density was located at $30-35 \mathrm{~cm}$. 


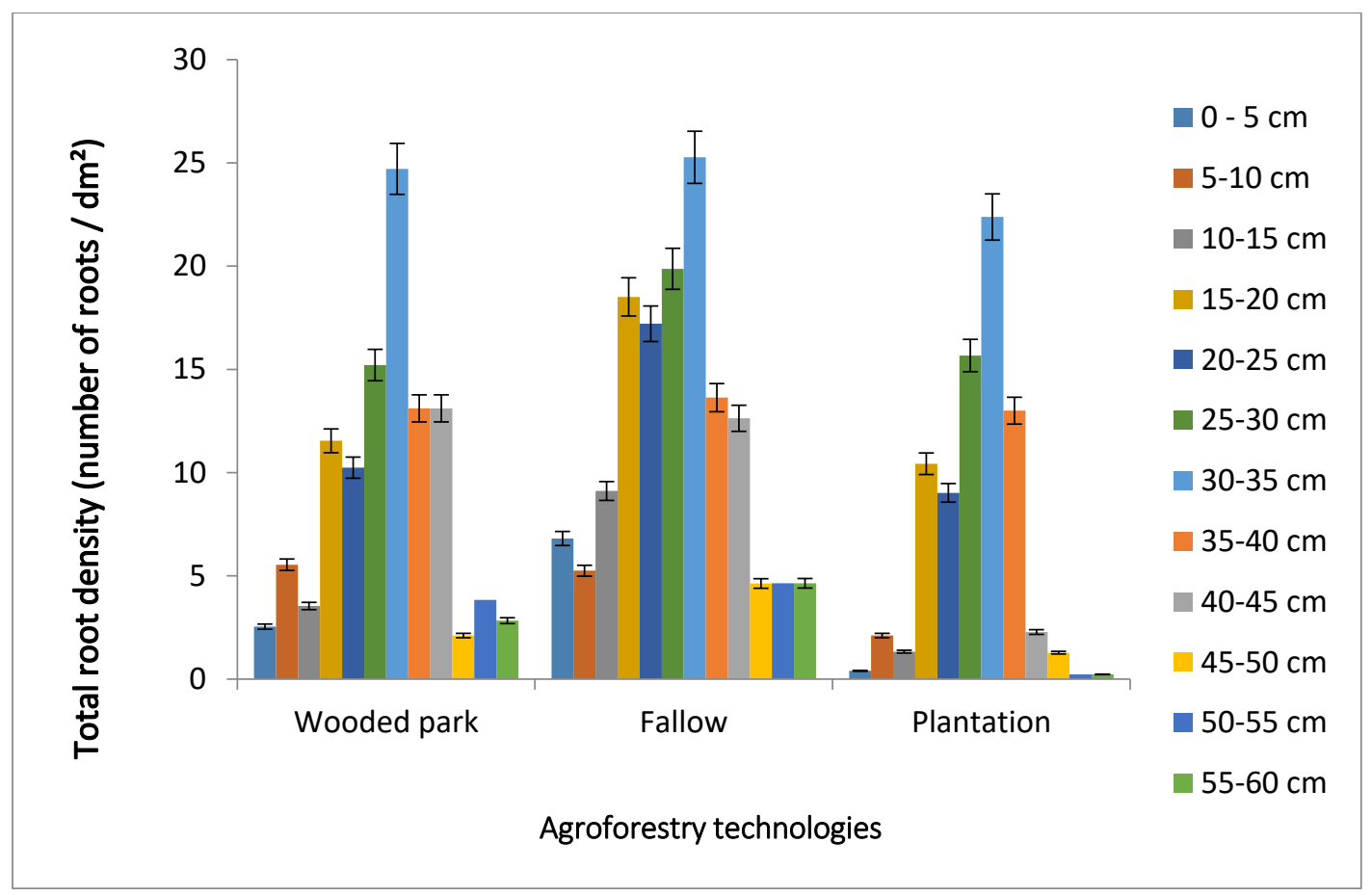

Figure 8. Influence of agroforestry technology on root biomass, depending on soil depth.

\section{Discussion}

Work on the deep distribution of roots in agroforestry systems is still rare. These results demonstrate that the rooting in light soil of the species Commiphora kerstingii, Erythrina sigmoidea, Ficus thonningii and Jatropha curcas is denser and deeper than the rooting of these species in heavy soil. The highest root densities are observed in the surface layers of the soil, ie the first $30 \mathrm{~cm}$. The results obtained show that the number of roots decreases rapidly after $30 \mathrm{~cm}$ of depth. The root densities are constantly decreasing as the depth increases. However, soil type tends to have an effect on rooting density in the bottom $30 \mathrm{~cm}$ of depth for all classes together; higher densities were obtained in light soil compared to heavy soil.

The difference in rainfall could explain the rooting in the two types of soil. In areas with insufficient rainfall, species tend to develop deep rooting [14,15].

The soil texture more generally influences the total root density in the profile; clay soils have the highest root densities, followed by sandy loam, sandy and loamy soils. The low amounts of root density found in sandy and loamy soils are linked to their particulate structure with few aggregates, and their lack of organic matter [16,17].

The fact that clay soils retain more organic matter $[18,19]$ would explain their higher production of root density; organic matter is better protected there from decomposition by the presence of aggregates. Their cation exchange capacity (CEC) and higher nutrient availability would also cause higher root density production [20,21]. Root density is higher in fallow land. This could be explained in part by a greater accumulation of organic matter fed by various residues produced by tree litter and by a well-supplied grass cover. Moreover, fallows accumulate more organic matter than cultivated areas $[22,23]$. On the other hand, the lower root biomass in wooded parks and in plantations is explained by their lack of organic matter, which limits the availability of nutrients, following unsuitable practices such as clearing, plowing and overgrazing. 


\section{Conclusion}

This is in order to better understand the interactions between trees and crops and by the very fact of improving their development as well as their integration in the SudanoSahelian zone of Cameroon that the study of the root systems of trees established in living hedges and in agroforestry technologies was undertaken. The results obtained show that the number of roots decreases rapidly after $30 \mathrm{~cm}$ of depth. The highest root densities are observed in the first $30 \mathrm{~cm}$. Soil type has a slight effect on rooting density in the last $30 \mathrm{~cm}$ of depth for all root classes, higher densities were obtained in light soil compared to heavy soil. Commiphora kerstingii stands out significantly by obtaining a higher number of roots than the other species for all classes. Among the technologies, the plantations showed the lowest root density at $0-5 \mathrm{~cm}$ and the highest at $55-60 \mathrm{~cm}$. The root density was higher in the fallows. The results of the study provide a first insight into the root morphological behavior of agroforestry species in semi-arid zones, in response to environments modulated by soils, their use and contrasting seasons.

Acknowledgements

We would like to thank all the referees whose contributions have been very important for the improvement of this manuscript.

Conflict of Interest

The author declares that there is no conflict of interest regarding the publication of this manuscript.

Author Contributions: Conceptualization, D.V.A. and N.N.V.; methodology, D.V.A.; software, B.T.A.V.; validation, N.N.V., D.V.A and L.Z.; formal analysis, D.V.A.; investigation, L.Z.; writingoriginal draft preparation, D.V.A.; writing-review and editing, B.T.A.V.; visualization, L.Z..; supervision, N.N.V and B.T.A.V. All authors have read and agreed to the published version of the manuscript.

Funding: This research received no external funding.

\section{References}

[1] Kubikova J. (1967). Contribution to the classification of root systems in woody plants. Preslia. 39: 236-243.

[2] Awé D.V.; Noiha N.V.;Zapfack L.;Vroh B.T.A.;Nyeck B. (2019). Vegetation Structure, Root Biomass Distribution and Soil Carbon Stock of Savannah Agrosystems in Sudano-Sahelian Zone of Cameroon. J Bot Res. 2(1) :68-77 .

[3] PavlychenkoT. K. (1942). Root systems of certain forage crops in relation to the management of agricultural soils. Nat. Res. Council Bull. 1088:46.

[4] Stout B.B. (1956). Studies of the root systems of deciduous trees. Black Rock Forest Bulletin. 15:1-45.

[5] David H.V.L.; Jack B.W.; Michael J.T.(1983). Biomass and nutrient content of a 41-year-old loblolly pine (Pinus taeda L.) plantation on a poor site in South Carolina. Forest Science. 30(2):395-404.

[6] Atger C.; Edelin C. (1994). First data on the comparative architecture of the root and caulinary systems of trees. Can J. Botany. 72 (7): 963-975.

[7] Plante P.M. (2012). Root distribution of three tree species planted in windbreak hedges according to two contrasting soil types. Thesis presented to the Faculty of Graduate and Postdoctoral Studies of Laval University as part of the master's program in agroforestry for obtaining the degree of Master of Science (M. Se.) for obtaining the degree of Master of Science (M. Se.). 80p.

[8] Marone D. (2015). Study of the carbon stock potential of agroforestry species and their functional traits in relation to land use systems in Senegal. PhD thesis in forest sciences, Laval University, Quebec, Canada. 166p.

[9] Eis S. (1987). Root systems of older immature hemlock, cedar, and Douglas-fir. Revue canadienne de recherche forestière. 17(11):1348-1354.

[10] Eis S. (1972). Root system morphology of western hemlock, western red cedar, and douglas-fir. Canadian Journal of Forest Research. 4:28-38.

[11] Danjon F.; Fourcaud T. (2009). The tree and its rooting. Agronomic Innovations Reviews. 6:17. 
[12] AFNOR. (2003). Water quality Determination of the macrophytic biological index in rivers (IBMR). French Association for Standardization T90-395, 28.

[13] Butterfield B. J.; Bradford J. B.; Munson S. M.; Gremer J. R. (2017). Aridity increases below-ground niche breadth in grass communities. Plant Ecol. 218:385-394.

[14] Daniel C. L.; Liesje M.; Francesco M.S.; Helge B.; Thom W. K.; Luke McCormack M.; Joana B.; Grégoire T. F.; Nathaly R.G.R.; Colleen M.I.; Jens K.; Ina C.M.; Hendrik P.; Catherine R.; Marina S.; Oscar J. V.B., Fons V.V. P.; Jasper V. R.; Larry M. Y.; Isabelle A.; Olivia R. B.; Chaeho B.; Renata Ć.; Jürgen D.; Estelle F.; Greg R. G.; Bruno H.; Robert B. J.; Dirk N. K.; Jonathan L.; Tatiana L.; Patrick M.; Ülo N.; Wim A. O.; Josep P.; Peter B. R.; Marco S.; Franziska S.; Eduardo V.; Alexandra W. (2021). Root traits explain plant species distributions along climatic gradients yet challenge the nature of ecological trade-offs. Nature Ecology E Evolution .5:1123-1134.

[15] Kramer-Walter K. R.; Bellingham P. J.; Millar T. R.; Smissen R. D.;Richardson S. J.; Laughlin D. C. (2016). Roots traits are multidimensional: specific root length is independent from root tissue density and the plant economic spectrum. J. Ecol. 104:1299-1310. doi: 10.1111/1365-2745.12562.

[16] Kubisch, P., Leuschner, C., Coners, H., Gruber, A., Hertel, D. (2017). Fine root abundance and dynamics of stone Pine (Pinus cembra) at the alpine treeline is not impaired by self-shading. Front. In Plant Sci. 8:602. doi: 10.3389/fpls.2017.00602.

[17] Li F.; Hu H.; McCormlack M. L.; Feng D. F.; Liu X.; Bao W. (2019). Community-level economics spectrum of fine-roots driven by nutrient limitations in subalpine forests. J. Ecol. 00:1-12. doi: 10.1111/1365-2745.13125.

[18] Valverde-Barrantes O. J.; Blackwood C. B. (2016). Root traits are multidimensional: specific root length is independent from root tissue density and the plant economic spectrum. J. Ecol. 104:1311-1313. doi: 10.1111/1365-2745.12605.

[19] Sierra Cornejo N.; Hertel D.; Becker J.N.; Hemp A.; Leuschner C .(2020). Biomass, Morphology, and Dynamics of the Fine Root System Across a 3,000-M Elevation Gradient on Mt. Kilimanjaro. Front. Plant Sci. 11:13. doi: 10.3389/fpls.2020.00013.

[20] Adamek M.; Corre M. D.; Hölscher D. (2011). Responses of fine roots to experimental nitrogen addition in a tropical lower montane rain forest, Panama. J. Trop. Ecol. 27:73-81. doi: 10.1017/S0266467410000507.

[21] Becker J. N.; Gütlein A.; Sierra C.N.; Kiese R.; Hertel D.; Kuzyakov Y. (2016). Legume and Non-legume Trees Increase Soil Carbon Sequestration in Savanna. Ecosystems. 20/989-999. doi: 10.1007/s10021-016-0087-7.

[22] Yong Z.; Stephen E. W.; Thomas W. B.; Steven R. A.(2019). Root density distribution and biomass allocation of co-occurring woody plants on contrasting soils in a subtropical savanna parkland. Plant and Soil. 438:263-279. https://doi.org/10.1007/s11104-019-04018-9.

[23] Waring B. G.; Powers J. S. (2017). Overlooking what is underground: Root: shoot ratios and coarse root allometric equations for tropical forests. Forest Ecology and Management. 385:10-15. doi:10.1016/j.foreco.2016.11.007. 